\title{
Notes on the geographic distribution and subspecific taxonomy of Sais rosalia (Cramer) (Lepidoptera, Nymphalidae, Ithomiini), including the first records in Paraguay
}

\author{
Sergio D. Ríos Díaz ${ }^{1}$, Fernando M. S. Dias², Mirna M. Casagrande², Olaf H. H. Mielke² \& Gerardo Lamas ${ }^{3}$
}

\begin{abstract}
${ }^{1}$ Museo Nacional de Historia Natural del Paraguay, Sucursal 1 Campus, Central XI, San Lorenzo, Paraguay. Facultad de Ciencias Exactas y Naturales. Universidad Nacional de Asunción. Corresponding author. sergiord40@gmail.com

${ }^{2}$ Departamento de Zoologia, Universidade Federal do Paraná, Laboratório de Estudos de Lepidoptera Neotropical, Caixa Postal 19.020. 81531-980 Curitiba-PR, Brazil. fernandomsdias@yahoo.com.br; mibras@ufpr.br; omhesp@ufpr.br

${ }^{3}$ Universidad Nacional Mayor de San Marcos, Museo de Historia Natural, Departamento de Entomología. Apartado 14-0434. Lima, Perú. glamasm@unmsm.edu.pe,paititia@yahoo.com
\end{abstract}

\begin{abstract}
Notes on the geographic distribution and subspecific taxonomy of Sais rosalia (Cramer) (Lepidoptera, Nymphalidae, Ithomiini), including the first records in Paraguay. This paper provides comments on the subspecific taxonomy and geographic distribution of Sais rosalia (Cramer, 1779) (Lepidoptera, Nymphalidae, Ithomiini), as well as an up-to-date distributional map, complemented with unpublished distributional data based on specimens deposited in the Coleção Entomológica Pe. Jesus S. Moure, Curitiba, Brazil and the Museo de Historia Natural, Lima, Peru. The following synonyms are proposed: Sais rosalia camariensis Haensch, 1905 syn. rev. as junior subjective synonym of Papilio rosalia Cramer, 1779 and Sais rosalia brasiliensis Talbot, 1928 syn. rev. as junior subjective synonym of Sais rosalia rosalinde Weymer, 1890. Additionally, the first country records of Sais rosalia in Paraguay, including the southernmost record of the species, are documented.
\end{abstract}

KEYWORDS. Butterfly; distribution; Insecta; Neotropics; subspecies; taxonomy.

Sais Hübner, 1816 is an unmistakable Neotropical genus of the Ithomiini (Nymphalidae, Danainae) characterized by the long discal cell of the hindwing, elongated to nearly seven eights of the wing length, and the condition of the Sc and $\mathrm{R}$ of the female hindwing, coalesced almost to the end of the discal cell (Fox 1967). The genus has been long acknowledged as belonging to Mechanitina, a subtribe recently recognized as monophyletic by Willmott \& Freitas (2006). The genus encompasses two species: S. browni Takahashi, 1977, distributed in southeastern Colombia and southern Venezuela (Takahashi 1977; Neild 2008), and Sais rosalia (Cramer, 1779), widely distributed throughout South America, from northern Colombia to southern and southeastern Brazil, with eleven recognized subspecies (Lamas 2004). Sais rosalia can be distinguished from S. browni by strong differences in color pattern, venation of the wings and by the presence of a long, instead of short, downward spine in the tip of the valva of $S$. rosalia (D'Almeida \& Fox 1941; Fox 1967; Takahashi 1977; Neild 2008). Sais rosalia flies low and slowly in the shade in somewhat open forest areas near swamps, rivers or streams, occasionally searching for flowering plants and resting on the undergrowth in the forest edges (Collenette \& Talbot 1928). The species uses as host plant a vine of the genus Lycianthes (Dunal) Hassl. (Solanaceae) and their immature stages are generally similar to other described Mechanitina (Drummond \& Brown 1987; Freitas \& Brown 2002).

\section{MATERIAL AND METHODS}

The distribution map and the information presented here are based on personal observations by the authors, original descriptions and type localities of the taxa involved, 413 specimens deposited in four collections from Brazil, Paraguay and Peru, and literature data (D’Almeida \& Fox 1941; Fox 1967; Brown \& Mielke 1967, 1968; Brown 1979; Brown 1987; Lamas 1994a,b,c,d; Mielke \& Casagrande 1992, 1998; Freitas \& Brown 2002; Motta 2002; Garwood et al. 2007); the taxonomy follows Lamas (2004) and Willmott \& Freitas (2006), modified after Wahlberg et al. (2009), who treated Ithomiini as a tribe, downranking previously recognized tribes to subtribes. The schematic illustrations of the habitus of the taxa are based on photographs of type specimens (Warren et al. 2013). The collections examined and their acronyms are as follows: CE-MTG/IB Colección de Entomología, Museo de la Tierra Guaraní, Itaipú Binacional, Hernandarias, Paraguay; CMNH - Carnegie Museum of Natural History, Pittsburgh, United States; DZUP Coleção Entomológica Pe. Jesus S. Moure, Universidade Federal do Paraná, Curitiba, Brazil; IOC - Instituto Oswaldo Cruz, Rio de Janeiro, Brazil; MfN - Museum für Naturkunde, Berlin, Germany; MNHNPY - Museo Nacional de Historia Natural del Paraguay, San Lorenzo, Paraguay; MUSM - Museo de Historia Natural, Universidad Nacional Mayor de San Marcos, Lima, Peru; NHM - Natural History Museum, London, England; NHRM - Naturhistoriska Riksmuseet, Stockholm, Sweden. 


\section{RESULTS AND DISCUSSION}

Paraguayan records. The first records of Sais rosalia from Paraguay (Figs. 1-3, 6) are two specimens from Refugio Biológico Mbaracayú, Department of Canindeyú, collected in March, 2004 (deposited in the CE-MTG/IB) (Figs. 2-3); another specimen was photographed and collected by the first author in a degraded forest patch in Hernandarias, Department of Alto Paraná, in December, 2011 (deposited in the MNHNPY) (Fig. 1). The specimens from Paraguay agree perfectly with the holotype of S. $r$. brasiliensis Talbot, 1928, a subspecies originally described from the state of Mato Grosso, Brazil (Fig. 6).

These are to date the southernmost records for Sais rosalia, a species generally regarded in the literature as "Amazonian", but also present in very restricted and local populations in the Atlantic interior forests, and intrusions of riparian forests within the Cerrado Biome. These records from Paraguay are not totally unexpected, as there are specimens collected on the left (east) banks of the Paraná River, in the border municipality of Guaíra, Paraná, Brazil; there is a single specimen caught in August, 1923, deposited in the DZUP and labeled "Guaíra, Alto [Upper] Paraná". Additionally, Olaf H. H. Mielke and Herbert Miers collected a large series of 56 specimens in February, 1978, in the now extinct Parque Nacional das Sete Quedas, and 12 more specimens were collected in the following years in the same region by Olaf H. H. Mielke and Mirna M. Casagrande, before the whole area was flooded by the reservoir of the Itaipu dam in 1982.

The tributaries of the Paraná River and the Paraná River itself were extensively collected in the past and recently by the authors and other collectors, and no new specimens were caught in the state of Paraná until recently, when three specimens were collected in the municipality of Diamante do Norte, one in October, 2009 and two in January, 2011, and a larger series of 22 specimens was collected and many more seen in the municipality of Alto Paraíso in October, 2012 (16 specimens deposited in the DZUP and 6 in MUSM). The Parque Nacional do Iguaçu, the largest remnant of Atlantic interior forest in the state, and several localities in the Misiones province, Argentina, were also extensively sampled through the years and no specimens of Sais rosalia were ever recorded (R. Greve, pers. comm., E. Núñez-Bustos, pers. comm.).

As regards neighboring areas along the River Paraná and its tributaries, there is still no record of Sais rosalia in the state of Mato Grosso do Sul (Brown 1987) and the most recent record in the state of São Paulo is a single specimen collected in the municipality of Teodoro Sampaio, in the Parque Estadual Morro do Diabo, in August, 1989 (Mielke \& Casagrande 1998), although there are records of Sais rosalia in other localities of the state of São Paulo from older collections (Fig. 6). As Brown \& Mielke (1967, 1968) and the available material suggest, Sais rosalia seems to be a very localized, but abundant species in small, particular locations and seasons.
Taxonomy and geographic distribution of the subspecies. As noted by Fox (1967), S. rosalia is so intraspecifically variable that it is difficult to separate into diagnosable subspecies and there seems to be little consensus on which name to apply to each phenotype (Table I). Significant individual variation can be observed even in specimens from a single locality and date. Fifteen names, including one nomen nu$d u m$, were proposed to describe that variation, although eleven names are currently regarded as valid (Lamas 2004). Other four (Brown 1979) or five (Lamas 2004) undescribed subspecies have also been listed (Table I), but no new taxon was described since 1953 (Bryk 1953).

The last comprehensive revisions of the genus were carried out by D'Almeida \& Fox (1941) and Fox (1967). While the former recognized five subspecies, $S$. r. rosalia (Cramer, 1779), S. r. promissa Weymer, 1883, S. r. mosella (Hewitson, 1867), S. r. zitella (Hewitson, 1868), and S. r. rosalinde (Weymer, 1890) (=S. paráensis [sic] Haensch, 1905), the latter recognized six, adding S. r. badia Haensch, 1905 as valid (Table I). If one follows the arrangement proposed by D'Almeida \& Fox (1941) and Fox (1967), the specimens from Paraguay and southern and southeastern Brazil would be identified as $S$. r. rosalinde. In fact, this is the name usually adopted by most authors who identified specimens from these localities (e.g. Brown \& Mielke 1967, 1968; Brown 1987; Mielke \& Casagrande 1998; Freitas \& Brown 2002; Motta 2002). However, based on the series of specimens deposited in the DZUP and MUSM, the characters used by Talbot (in Collenette \& Talbot 1928) to differentiate $S$. r. brasiliensis from $S$. r. rosalinde (as "paraensis") - reduction of the forewing yellow postdiscal band and of the hindwing black discal spots above, and diminished size of the hindwing white marginal spots below - are subject to individual and not geographical variation. Brown (1979) suggests a new subspecies ("phenotype 3", Table I) occurring in the states of Mato Grosso, Pará and Amazonas, Brazil, which conforms to the above described variation. Such variation does not appear to have a clinal nature or geographic correlation, since the same variation is observable along its entire distributional range. Therefore $S$. $r$. brasiliensis syn. rev. is considered herein a junior subjective synonym of $S$. r. rosalinde.

Sais rosalia badia was described from a vague, probably spurious locality ("Upper Amazon") and characterized only by the dark brownish red color of the wings. The taxon was regarded as a valid subspecies by Fox (1967) and D'Almeida (1978), but not by D'Almeida \& Fox (1941), who listed it as synonym of $S$. $r$. rosalinde (Table I). Probably the real type locality of $S$. $r$. badia is somewhere in Bolivia, as previously suggested by Fox (1967) and deducted from a series of five specimens deposited in the DZUP from Chapare, Cochabamba, Bolivia and two specimens, one brownish red, similar to the holotype of S. r. badia, and one dark orange, similar to a specimen illustrated by Garwood et al. (2007), with the same date and locality, collected in the Reserva Nacional de Tambopata, Peru. Additionally, a series of 17 specimens from Peru (Upper Purus River in Ucayali and Madre de Dios), and 

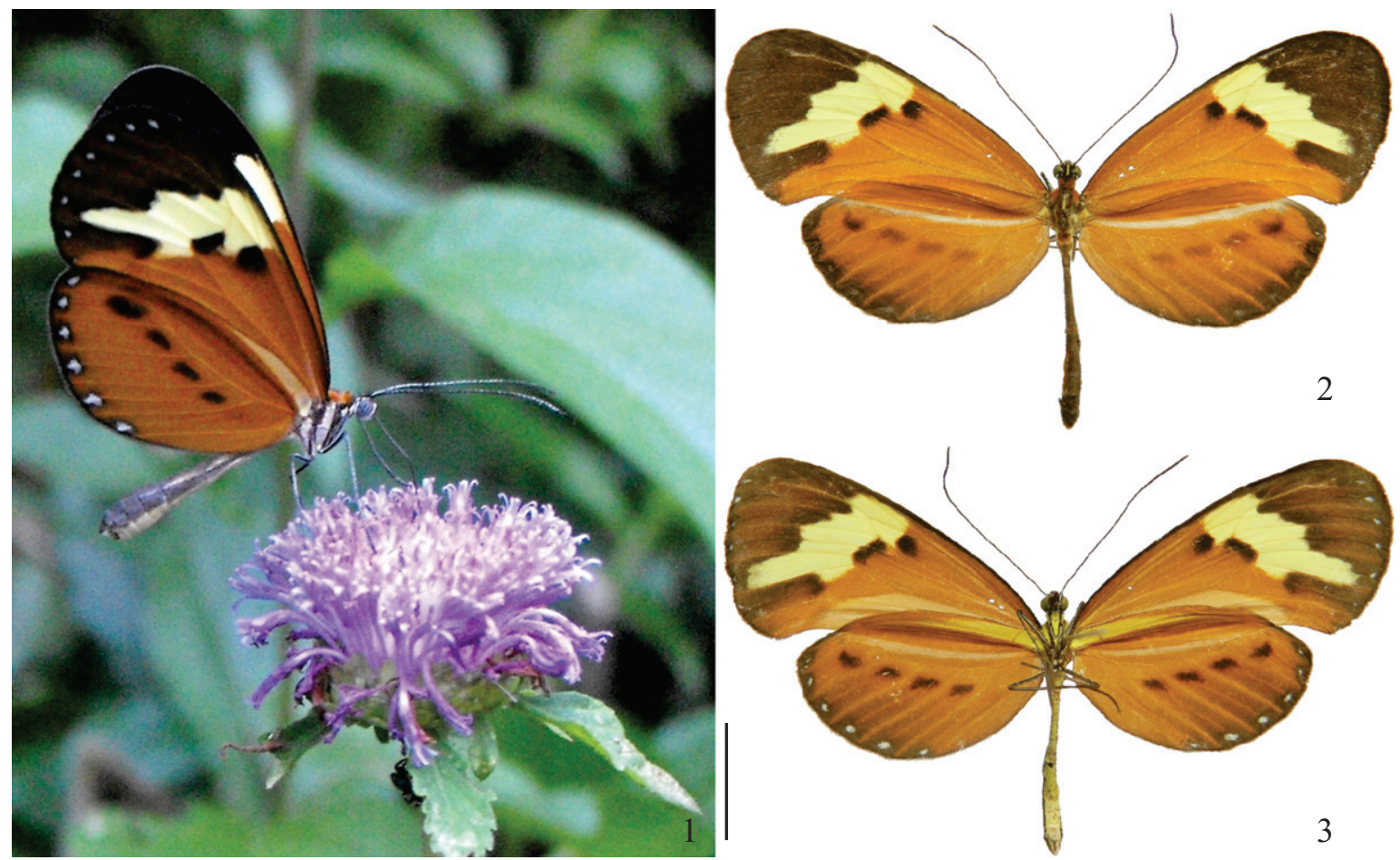

Figs. 1-3. Sais rosalia rosalinde Weymer, 1890 from Paraguay. 1. Live male specimen from Hernandarias, Department of Alto Paraná. 2-3. Male specimen from Mbaracayú, Department of Canindeyú. 2. Dorsal. 3. Ventral. Scale bar $=1 \mathrm{~cm}$.
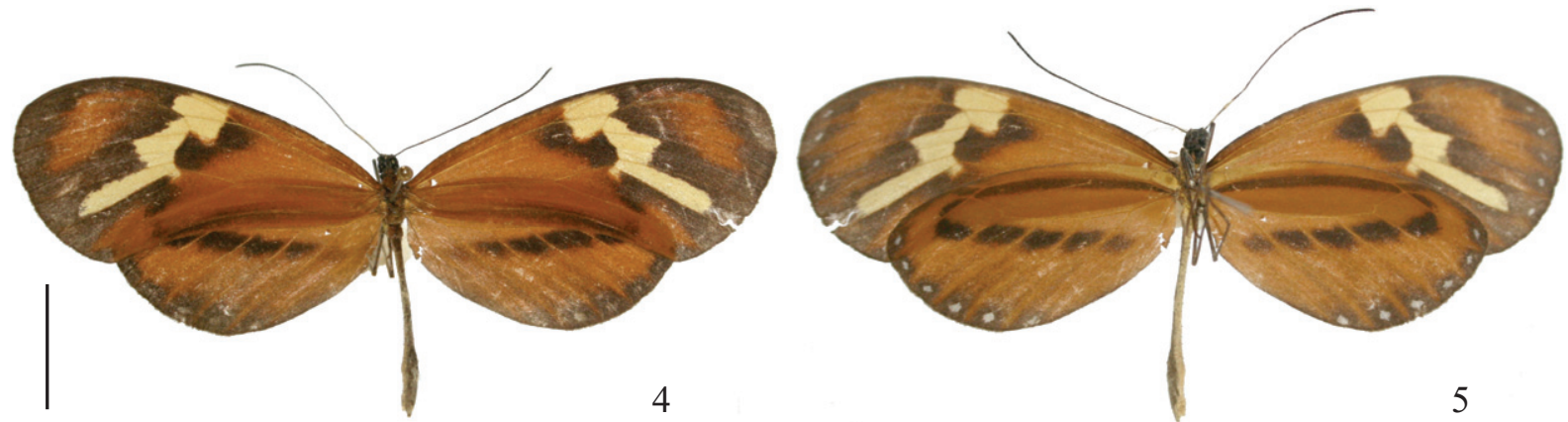

Figs. 4-5. Sais rosalia (Cramer, 1779) from Óbidos, Pará, Brazil; phenotype suggested as a new subspecies by Brown (1979) and Lamas (2004). 4. Dorsal. 5. Ventral. Scale bar $=1 \mathrm{~cm}$.

one from Bolivia (Cochabamba) are housed at MUSM. Sais rosalia badia seems to be associated with the southeastern Peruvian and northwestern Bolivian Amazon River basin (i.e. Rio Madeira drainage), which includes the Purus, Madre de Dios, Beni and Mamoré Rivers and the west drainage of the Guaporé River (Fig. 6).

Of the other taxa not previously associated with $S$. $r$. rosalinde, S. r. mosella and S. r. virchowii Dewitz, 1877 represent two geographically isolated populations in north South America, the first occurring in extreme northern Colombia, the second extending from central Colombia and northwestern Venezuela, east to the Orinoco River delta-(Fig. 6). D’Almeida \& Fox (1941), Fox (1967) and D'Almeida (1978) agree that they represent the same subspecies. Brown (1979) suggested the presence of a new subspecies ("phenotype 1", Table I, Fig. 6) in the Catatumbo region of Venezuela but, as discussed by Neild (2008), the phenotype occurring in that region most likely represents intergrades between populations of $S$. r. mosella and S. r. virchowii, although no typical mosella have been found in Venezuela.

Sais rosalia rosalia occurs in northeastern and southern Venezuela east of the Orinoco River delta, Guyana, Suriname, French Guiana, the Brazilian states of Roraima, Amazonas and Pará north of the Amazon River, and in northwestern Maranhão, southeast of the Amazon delta (Fig. 6) (D'Almeida \& Fox 1941; Fox 1967; D’Almeida 1978). Brown (1979) and Lamas (2004) recognize $S$. r. rosalia and $S$. r. camariensis as two distinct subspecies, separated by the Essequibo River, Guyana: S. r. camariensis to the west and S. r. rosalia to the east of that river (Brown 1979). However, examining the types of those names and a series of 43 specimens deposited in the DZUP and the MUSM, S. r. camariensis Haensch, 1905 syn. 
Table I. Subspecific taxonomy of Sais rosalia (Cramer, 1779) according to some authors and their type localities. Equal signs indicate synonyms; author names in parenthesis indicate the authority of phenotypes previously supposed to be new taxa, according to Lamas (2004); country names in quotation marks and parenthesis indicate spurious type locality and probable type locality, respectively. Question mark indicates a taxon with an unknown phenotype and distribution. AM: Amazonas; PA: Pará; MT: Mato Grosso.

\begin{tabular}{|c|c|c|c|c|c|c|}
\hline $\begin{array}{l}\text { D'Almeida \& } \\
\text { Fox (1941) }\end{array}$ & Fox (1967) & D'Almeida (1978) & Brown (1979) & Lamas (2004) & This study & Type Locality \\
\hline rosalia & rosalia & rosalia & rosalia & rosalia & rosalia & Suriname \\
\hline \multirow[t]{4}{*}{$=$ camariensis } & $=$ camariensis & $=$ camariensis & camariensis & camariensis & = camariensis syn. rev. & Guyana \\
\hline & & & & & $=$ phenotype $2(\mathrm{~K}$. Brown $)$ & Brazil (AM, PA) \\
\hline & & & & & $=$ phenotype $3(\mathrm{~K}$. Brown $)$ & Central Brazil \\
\hline & & & & & $=$ phenotype 4 (G. Lamas) & Guyana \\
\hline \multirow[t]{2}{*}{ mosella } & mosella & mosella & mosella & mosella & mosella & "Venezuela" (Colombia) \\
\hline & & & & & $=$ phenotype 5 (G. Lamas) & Colombia \\
\hline \multirow[t]{2}{*}{$=$ virchowii } & $=$ virchowii & $=$ virchowii & virchowii & virchowii & virchowii & Venezuela \\
\hline & & & phenotype 1 & phenotype 1 (G. Lamas) & $=$ phenotype 1 (G. Lamas) & Venezuela \\
\hline \multirow[t]{3}{*}{ promissa } & promissa & promissa & promissa & promissa & promissa & Brazil (AM) \\
\hline & $=$ schatzi & $=$ schatzi & schatzi & schatzi & schatzi & Brazil (AM) \\
\hline & $=$ sancti-bernardi & $=$ sancti-bernardi & $=$ sancti-bernardi & $=$ sancti-bernardi & $=$ sancti-bernardi & Colombia \\
\hline \multirow[t]{3}{*}{$=$ klages $i$} & $=$ klagesi & $=$ klagesi & klagesi & klagesi & klagesi & Brazil (AM) \\
\hline & $=$ huebneri & $=$ huebneri & $=$ huebneri & $=$ huebneri & $=$ huebneri & Brazil (AM) \\
\hline & & & phenotype 2 & phenotype 2 (K. Brown) & & Brazil (AM, PA) \\
\hline rosalinde & rosalinde & rosalinde & rosalinde & rosalinde & rosalinde & Brazil (PA) \\
\hline$=$ paraensis & $=$ paraensis & $=$ paraensis & $=$ paraensis & $=$ paraensis & $=$ paraensis & Brazil (PA) \\
\hline$=$ brasiliensis & $=$ brasiliensis & $=$ brasiliensis & brasiliensis & brasiliensis & = brasiliensis syn. rev. & Brazil (MT) \\
\hline \multirow[t]{3}{*}{$=$ badia } & badia & badia & badia & badia & badia & "Upper Amazon" (Bolivia) \\
\hline & & $=$ mosellina & & = mosellina nom. nud. & $=$ mosellina nom. nud. & - \\
\hline & & & phenotype 3 & phenotype 3 (K. Brown) & & Central Brazil \\
\hline \multirow[t]{3}{*}{ zitella } & zitella & zitella & zitella & zitella & zitella & Peru \\
\hline & & & phenotype 4 & phenotype 4 (G. Lamas) & & Guyana \\
\hline & & & & ?phenotype 5 (G. Lamas) & & Colombia \\
\hline
\end{tabular}

nov. is recognized as a junior subjective synonym of $S$. $r$. rosalia. Brown (1979) suggests the occurrence of an undescribed subspecies ("phenotype 4", Table I, Fig. 6) similar to $S$. r. rosalia, but with a mostly black hindwing, in southeastern Guyana. The undescribed subspecies is probably just a melanic form of $S$. r. rosalia. Another undescribed subspecies ("phenotype 2", Table I, Fig. 6), occurring between the junction of the Negro and Solimões Rivers, and the Trombetas River is suggested by Brown (1979). There are in the DZUP a series of three specimens from Óbidos, Pará, which agree perfectly with the illustration presented by Brown (1979) for this undescribed taxon. All three specimens are similar to $S$. r. rosalia, but with very narrow yellow postdiscal band in the forewing and generally darker in color (Figs. 4-5). A possible original syntype of rosalia in Leiden (ex Calkoen), from Surinam, also has a narrow FW yellow postdiscal band.

Six names where proposed to describe specimens from the western part of the Amazon basin, although only four are currently accepted as valid (Table I): S. r. klagesi Avinoff, 1926 (= S. promissa race huebneri Zikán, 1941), S. r. promissa, S. r. schatzi Zikán, 1941 (= S. rosalia sanctibernardi [sic] Bryk, 1953) and S. r. zitella. Fox (1967) and D'Almeida (1978) retained only two of these: S. r. zitella, distributed in the extreme west of the state of Amazonas, western Acre, extreme southeastern Colombia, eastern Ecuador, and central and northern Peru; and S. r. promissa, in southern and southwestern Amazonas, central and eastern Acre, northern Rondônia, extreme northern Peru and southern Colombia. Both taxa are easily characterized by the large black longitudinal stripes between some veins of the hindwing and the darker, brownish red color of the base of the wings. Examining the types, 32 specimens deposited in the DZUP and 34 specimens in MUSM, S. r. zitella generally has the yellow postdiscal band narrow and the submarginal orange area well developed along the whole outer margin of the forewing, while $S$. r. promissa has the yellow postdiscal band wide and the submarginal orange area rudimentary or absent. There is, however, much individual variation and intermediate specimens between these phenotypes, especially in the triple boundary between Brazil, Peru, and Colombia, where the two phenotypes occur sympatrically, in various combinations. Nevertheless, $S$. $r$. zitella appears to be associated with the Napo and Ucayali basins in Peru, and the upper Juruá basin in Brazil, and S. r. promissa with the lower Putumayo and Caquetá Rivers in Colombia (Içá and Japurá Rivers in Brazil, respectively) and other rivers to the south of the Solimões and the Amazon River in Brazil, east to the Madeira River (Fig. 6).

Of the two remaining currently recognized taxa only $S$. $r$. schatzi is clearly distinct, being lighter in color when compared with $S$. r. promissa and S. r. zitella; with wide postdiscal yellow band, and without submarginal orange band on the forewing, and mostly orange hindwing with reduced black discal spots. Sais rosalia schatzi occurs along the upper Negro and Vaupés Rivers (Uaupés River in Brazil) and tributaries in the extreme northwest of the state of Amazonas, southern Venezuela, southeastern Colombia and in extreme northern Peru (Brown 1979; Neild 2008). This subspecies 


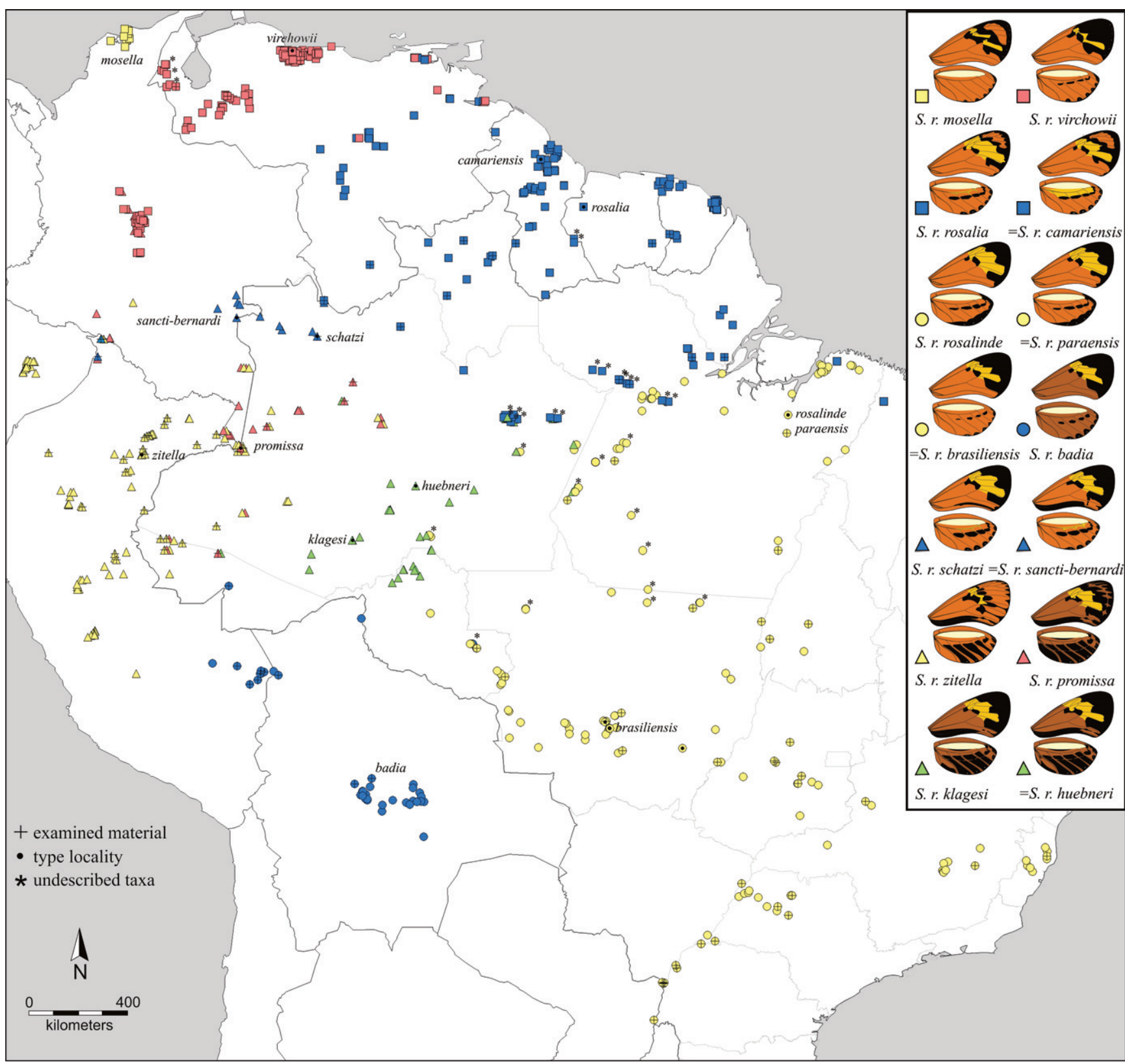

Fig. 6. Distribution map and schematic illustrations of the subspecies of Sais rosalia (Cramer, 1779). Dotted and/or crossed marks indicate type localities and examined material, respectively. Asterisk marks indicate a phenotype suggested as a new subspecies by Brown (1979) and/or Lamas (2004). Equal signs indicate synonyms.

intergrades with $S$. $r$. rosalia in the northern part of its distribution (Fig. 6) (Neild 2008). Conversely, Sais rosalia klagesi is very similar to $S$. r. promissa but occurs in the middle and lower Solimões (Amazon River), Purus and Madeira Rivers (Fig. 6) (Brown 1979), representing the darker phenotype with wide postdiscal yellow band and without the submarginal dark orange band on the forewing.

The use and usefulness of the subspecies rank is a contentious matter (Wilson \& Brown 1953; Mallet 2007) and subspecies recognition and delimitation are highly subjective practices, even more considering mimetic species with high individual variation and intermediate phenotypes in intraspe- cific hybridization zones. However, the subspecies concept may prove useful for those interested in intraspecific geographical variation and parapatric speciation models. Such a concept is helpful as a means of describing the variability in the biology and ecology of infraspecific units (Lanyon 1982), such as variation in behavior, host plant use, morphology, biogeography, and genetic composition (Brown 1975).

Material examined. Sais rosalia badia. "Ober Amazon" (Holotype of Sais badia Haensch, 1905, NHM). BOLIVIA. Cochabamba: Chapare, 15.XII.1948, Zischka leg. (3 specimens, DZUP); Chapare, 2.I.1948, Zischka leg. (2 specimens, DZUP); Chapare, Todos Santos, VII.1964, Steinbach leg. (1 specimen, MUSM). COLOMBIA. Peale leg. (1 speci- 
men, DZUP). PERU. Madre de Dios: R.N. Tambopata, 27.X.1991, Mielke leg. (1 specimen, DZUP); R.N. Tambopata, 28.X.1991, Casagrande leg. (1 specimen, DZUP); Tambopata, I.1995. Fratello leg. (2 specimens, MUSM); Puerto Maldonado, 23.X.1975, Schunke leg. (1 specimen, MUSM); $15 \mathrm{~km}$ E Puerto Maldonado, 7.XI.1988. Lamas leg. (1 specimen, MUSM); $15 \mathrm{~km}$ E Puerto Maldonado, 20.VI.1989. Lamas leg. (1 specimen, MUSM); Boca Río La Torre, 23.IX.1981, Lamas leg. (1 specimen, MUSM); Boca Río La Torre, 2.X.1981, Lamas leg. (1 specimen, MUSM); Boca Río La Torre, 3.X.1981, Lamas leg. (1 specimen, MUSM); Boca Río La Torre, 27.X.1981, Lamas leg. (1 specimen, MUSM); Boca Río La Torre, 22.X.1982, Lamas leg. (1 specimen, MUSM); Boca Río La Torre, 2.III.1983, Lamas leg. (1 specimen, MUSM); Boca Río La Torre, 17.IX.1989, Lamas leg. (1 specimen, MUSM); Pampas del Heath, 16.VI.1992, Lamas leg. (1 specimen, MUSM); Pampas del Heath, 18.VI.1992, Lamas leg. (1 specimen, MUSM); Río Los Amigos, 7.VII.2003, Peña leg. (1 specimen, MUSM); Río Los Amigos, 23.VIII.15.IX.2008, Carbonel leg. (1 specimen, MUSM). Ucayali: Río Purus, San Bernardo, 30.V.-8.VI.2000, Hocking leg. (1 specimen, MUSM). Sais rosalia klagesi. BRAZIL. Amazonas: Huitanaa, III.1922, Klages leg. (Type of Sais rosalia klagesi Avinoff, 1926, CMNH); Rio Purus, IV.1927, Zikán leg. (Holotype of Sais promissa r. huebneri Zikán, 1941, IOC). Sais rosalia mosella. COLOMBIA. "Venezuela" (Syntype of Ithomia mosella Hewitson, 1867, NHM). Sais rosalia promissa. BRAZIL. Acre: Médio Juruá (1 specimen, DZUP); Fonte Boa, XI.1937, Wuderpfemmig leg. (3 specimens, DZUP); Tarauacá, 30.XII.1957, Ebert leg. (1 specimen, DZUP); Tarauacá, 26.V.1977, Ebert leg. (4 specimens, DZUP). Amazonas: Tabatinga, 1881 (Lectotype of Sais promissa Weymer, 1883, MfN); Benjamin Constant, VIII. 1942, Parko leg. (1 specimen, DZUP); São Paulo de Olivença, 6.IV.1961, Kesselring leg. (1 specimen, DZUP); São Paulo de Olivença, X.1961. Ebert ex-coll. (1 specimen, DZUP); São Paulo de Olivença, XII.1961, Ebert ex-coll. (1 specimen, DZUP); Rio Japura, Copaçu, II.1964, Büche leg. (1 specimen, MUSM). Sais rosalia rosalia. BRAZIL. Amapá: Serra do Navio, 26.VII.2007, Mielke \& Casagrande leg. (4 specimens, DZUP). Amazonas: 7.VI.2010, Mielke \& Casagrande leg. (4 specimens, DZUP); Ararão, Padauari, 10.VII.2010, Mielke \& Casagrande leg. (6 specimens, DZUP); Negro, Carvalho leg. (1 specimen, DZUP). Pará: Óbidos, IV.1969, Kesselring leg. (3 specimens, DZUP); Puxuri, Paru do Leste, 18.VII.1952, Carvalho leg. (3 specimens, DZUP); Puxuri, Paru do Leste, 2.VIII.1952, Carvalho leg. (1 specimen, DZUP); Trompetas, IBDF, 7.XII.1978, Rauy leg. (1 specimen, DZUP). Roraima: $10 \mathrm{~km}$ E, $2^{\circ} 50^{\prime} \mathrm{N} 60^{\circ} 35^{\prime} \mathrm{W}, 12 . X I .1979$, Gifford leg. (5 specimens, DZUP); Catrimani, $1^{\circ} 45^{\prime} \mathrm{N} 62^{\circ} 17^{\prime}$ W, 9.XI.1979, Gifford leg. (2 specimens, DZUP); Ilha de Maracá, 14.XI.1979, Gifford leg. (2 specimens, DZUP); Ilha de Maracá, 20.XI.1979, Gifford leg. (1 specimen, DZUP); Ilha de Maracá, 21.XI.1979, Gifford leg. (4 specimens, DZUP); Ilha de Maracá, 22.XI.1979, Gifford leg. (3 specimens, DZUP); Ilha de Maracá, 23.XI.1979, Gifford leg. (1 specimen, DZUP); Ilha de Maracá, 31.VIII.1987, Mielke \& Casagrande leg. (7 specimens, DZUP); Ilha de Maracá, 2.XII.1987, Mielke \& Casagrande leg. (2 specimens, DZUP). FRENCH GUIANA. (2 specimens, DZUP). Inini: Maripasoula, 17.XII.1986 (1 specimen, MUSM); Maripasoula, 3.V.1987 (1 specimen, MUSM). GUIANA. Cuyuni-Mazaruni: Camaria (Lectotype of Sais camariensis Haensch, 1905, MfN). Upper Takutu-Upper Essequibo: Rupununi Cattle, Essequibo-Demerara, IV.1940 (1 specimen, DZUP). SURINAME. Marowijne: Anapaike, Rio Lawa, 27.XI.1963, Malkin leg. (1 specimen, MUSM). Sipaliwini: Tijgerdam, IV.1966, De la Fontaine leg. (Neotype of Papilio rosalia Cramer, [1779], CMNH) VENEZUELA. Amazonas: Ocama, 16.IV.1965, Fernández leg. (MUSM). Sais rosalia rosalinde. BRAZIL. Amazonas: Negro (1 specimen, DZUP). Espírito Santo: Linhares, IX.1981, Elias leg. (5 specimens, DZUP); Linhares, IX.1982, Elias leg. (4 specimens, DZUP). Goiás: Campinas, 16.XII.1935 (2 specimens, DZUP); Córrego Paciencia, 30.VI.1980 (1 specimen, DZUP); Goiás Velho, 20.VI.1976, Gifford leg. (1 specimen, DZUP); Goiânia, 24.V.1969, Brown leg. (3 specimens, MUSM); Goiânia, 11.X.1969, Brown leg. (6 specimens, MUSM); Nova Gloria, 2.IX.1978 (1 specimen, DZUP). Mato Grosso: Tombador, S Diamantino, 2027.VIII.1927, Collenette leg. (Holotype of Sais rosalia brasiliensis Tal- bot, 1928, NHM); Arinos, Faz, São João, 31.VII.1979, Furtado leg. (2 specimens, DZUP); Arinos, Faz, São João, 24.VIII.1985, Furtado leg. (1 specimen, DZUP); Barra do Garças, 25.VII.1968, Elias leg. (10 specimens, DZUP); Barra do Garças, 16.I.1977, Elias leg. (2 specimens, DZUP); Chapada dos Guimarães, 26.VI.1972, Mielke \& Brown leg. (1 specimen, DZUP); Paraguai, 14.IV.1974, Furtado leg. (1 specimen, DZUP); Paraguai, 29.VII.1974, Ebert leg. (2 specimens, DZUP); Serra Norte, 8.IX.1978, Gifford leg. (1 specimen, DZUP); Xingu, 18.VII.1978, Gifford leg. (11 specimens, DZUP); Xingu, 20.VII.1978, Gifford leg. (3 specimens, DZUP); Barra do Tapirapé, XI.1964, Malkin leg. (1 specimen, DZUP). Minas Gerais: Doce, III.1951, Machado leg. (1 specimen, DZUP); Doce, 20.IX.1974 (5 specimens, DZUP); Paracatu, 15.V.1969, Ebert leg. (1 specimen, DZUP); Paracatu, 13.IX.1969, Ebert leg. (1 specimen, DZUP); P.E. do Rio Doce, 14.XII.1971, Ebert leg. (1 specimen, DZUP); P.E. do Rio Doce, 8.IX.1972, Ebert leg. (1 specimen, DZUP); P.E. do Rio Doce, 14.XII.1972, Ebert leg. (1 specimen, DZUP); P.E. do Rio Doce, 19.I.1974, Ebert leg. (1 specimen, DZUP); P.E. do Rio Doce, 19.II.1972, Ebert leg. (1 specimen, DZUP); P.E. do Rio Doce, 13.V.1974, Ebert leg. (1 specimen, DZUP); P.E. do Rio Doce, 19.XII.1974, Ebert leg. (1 specimen, DZUP). Pará: Rio Tocantins, 22.IX.1875 (Holotype of Sais rosalia rosalinde Weymer, 1890, MfN); 1.II. 1895 (Lectotype of Sais paraensis Haensch, 1905, MfN) Alcocaba, Tucuruí (1 specimen, DZUP); Belém Brasilia, km 567, 3.IX.1978, Gifford leg. (1 specimen, DZUP); Jacareacanga, 13.IX.1978, Gifford leg. (1 specimen, DZUP); Redenção, 19.VII.1976 (1 specimen, DZUP); Rio Ari, km 1288 Cuiabá-Santarém, 19.VII.1978, Callaghan leg. (1 specimen, MUSM). Paraná: E.E. Caiuá, 6.X.2009, Carneiro, Dias, Dolibaina \& Leite leg. (1 specimen, DZUP); E.E. Caiuá, 28.I.2012, Dolibaina \& Salik (2 specimens, DZUP); Fazenda Lupus, 3.X.2012, LELM \& Lamas leg. (16 specimens, DZUP); Guaíra, 1.V.1980, Mielke \& Casagrande leg. (2 specimens, DZUP); Guaíra, 5.III.1981, Mielke \& Casagrande leg. (9 specimens, DZUP); Guaíra, 8.X.1982, Mielke \& Casagrande leg. (1 specimen, DZUP); Paraná, 8.VIII.1923 (1 specimen, DZUP); P.N. das Sete Quedas, 16.II.1978, Mielke \& Casagrande leg. (56 specimens, DZUP); P.N. Ilha Grande, 3.X.2012, Lamas leg. (5 specimens, MUSM); P.N. Ilha Grande, 4.X.2012, Lamas leg. (1 specimen, MUSM). Rondônia: Pimenta Bueno, V-VI.1970, Brown leg. (3 specimens, DZUP); Pimenta Bueno, VI.1970, Brown leg. (3 specimens, MUSM); Pimenta Bueno, VIII.1970, Brown leg. (5 specimens, DZUP); Pimenta Bueno, VIII-IX.1970, Brown leg. (3 specimens, DZUP); Pimenta Bueno, IX-X.1970, Brown leg. (1 specimen, DZUP); Pimenta Bueno, 4.VI.1971, Ebert leg. (2 specimens, DZUP); Pimenta Bueno, 9.VI.1971, Ebert leg. (1 specimen, DZUP); Vilhena, 21.IX.1978, Gifford leg. (1 specimen, DZUP). São Paulo: 15.V.1962, Ebert leg. (1 specimen, DZUP); Auanhandava, VI.1950, Berla leg. (2 specimens, DZUP); Dos Dourados, 3.III.1951, Hashimoto leg. (1 specimen, DZUP); Ilha Solteira, 16.VII.1972, Mielke \& Brown leg. (4 specimens, DZUP); P.E. Morro do Diabo, 19.VIII.1989, Mielke \& Casagrande leg. (1 specimen, DZUP). Tocantins: Ilha do Bananal, Gifford leg. (1 specimen, DZUP); Ilha do Bananal, 7.IX.1978 Gifford leg. (3 specimens, DZUP);Ilha do Bananal, 14.VI.1979, Gifford leg. (2 specimens, DZUP); Ilha do Bananal, 21.VI.1979 Gifford leg. (6 specimens, DZUP); Ilha do Bananal, 22.VI.1979 Gifford leg. (1 specimen, DZUP); Ilha do Bananal, 23.VI.1979 Gifford leg. (3 specimens, DZUP); Ilha do Bananal, 21.VI.1979 Gifford leg. (6 specimens, DZUP); Ilha do Bananal, 24.VI.1979 Gifford leg. (5 specimens, DZUP); Ilha do Bananal, 29.VI.1979 Gifford leg. (6 specimens, DZUP); Ilha do Bananal, 11.IX.1979 Gifford leg. (1 specimen, DZUP); Ilha do Bananal, IX.1980 Gifford leg. (2 specimens, DZUP). PARAGUAY. Alto Paraná: Hernandarias, 28.XII.2011, Ríos Díaz leg. (1 specimen, MNHNPY). Canindeyú: Refugio Mbaracayú, 20.III.2004, Drechsel leg. (2 specimens, CE-MTG/IB).Sais rosalia schatzi. BRAZIL. Amazonas: São Gabriel da Cachoeira, V.1933, Zikán leg. (Lectotype of Sais rosalia schatzi Zikán, 1941, IOC); São Gabriel da Cachoeira, 11.V.1951, Falco leg. (1 specimen, DZUP); São Gabriel da Cachoeira, 23.VI.1951, Falco leg. (1 specimen, DZUP); São Gabriel da Cachoeira, 4.IX.1951, Falco leg. (1 specimen, DZUP). PERU. Loreto: Castaña, 20.IX.1993, Lamas leg. (1 specimen, MUSM); Río Putumayo, Soplín Vargas, 20.V.2010, Ramírez leg. (7 specimens, MUSM); Río Putumayo, Soplín Vargas, XII.2010, 
Lequerica leg. (5 specimens, MUSM). COLOMBIA. Vaupés: San Bernardo, 6.VI.1924 (Type of S. rosalia sancti-bernardi Bryk, 1953, NHRM). Sais rosalia virchowii. VENEZUELA. Barinas: Barinitas, El Mijao, 1.III.1965, Fernández \& Rosales leg. (1 specimen, MUSM). Carabobo: Yuma, 12.II.1976, Fernández \& Rosales leg. (2 specimens, MUSM); Yuma, 18.VII.1981, Lamas leg. (1 specimen, MUSM); Puerto Cabello, Virchow leg. (Holotype of Sais rosalia var. virchowii Dewitz, 1877, MfN) Zulia: Misión El Rosario, 12-13.I.1977, Loly. Salcedo \& Clavijo leg. (1 specimen, MUSM). Sais rosalia zitella. BRAZIL. Acre: D'Almeida ex-coll. (1 specimen, DZUP); Cruzeiro do Sul, 9.VII.1975, Ebert leg. (1 specimen, DZUP); Japiim, Pentecostes, 8.V.2011, Mielke \& Casagrande leg. (1 specimen, DZUP); Juruá, May ex-coll. (1 specimen, DZUP); Juruá, VII.1973 (1 specimen, DZUP); Juruá, 7.VIII.1973, Ebert leg. (1 specimen, DZUP); Juruá, 11.IX.1973 (3 specimens, DZUP); Juruá, 10.VII.1975 (2 specimens, DZUP); Juruá, 15. III.1979 (1 specimen, DZUP); Liberdade, 15.V.2011, Mielke \& Casagrande leg. (6 specimens, DZUP). Amazonas: Benjamin Constant, II.1942, Parko leg. (1 specimen, DZUP); Benjamin Constant, VIII.1942, Parko leg. (2 specimens, DZUP); Eirunepê, Gregório, 10.V.2011, Mielke \& Casagrande leg. (11 specimens, DZUP); Tabatinga, 10.V.1947, D’Almeida ex-coll. (2 specimens, DZUP). PERU. Loreto: Nauta (Holotype of Ithomia zitella Hewitson, 1868, NHM); Canal de Puinahua, 2,37km ENE de Bretaña, 22-23.X.2012, Grados leg. (2 specimens, MUSM); Boca Río Samiria, 9.VI.1990, Lamas leg. (1 specimen, MUSM); Río Samiria, E.B. Pithecia, 8.XI.1979, Pacheco leg. (1 specimen, MUSM); Río Samiria, Cocha Shinguito, 19.VI.1990, Silva leg. (1 specimen, MUSM); Río Samiria, cerca de Gloria, 5.X.2002, Joron leg. (5 specimens, MUSM); Buenos Aires (frente a Iquitos), 4.X.1975, Lobin leg. (1 specimen, MUSM); Iquitos, Padre Isla, XII.1984, Arévalo leg. (1 specimen, MUSM); Río Ampiyacu, Pebas, IX.1991, Lequerica leg. (2 specimens, MUSM); Río Chambira, II.1993, Büche leg. (1 specimen, MUSM); Río Marañón, San Regis, 9.VIII.2002, Ramirez leg. (1 specimen, MUSM); Río Morona, XI.1996, Büche leg. (1 specimen, MUSM); Río Nanay, Mishana, E.B. Callicebus, 17.VII.1984, Lamas leg. (2 specimens, MUSM); Río Napo, Sucusari, XII.1997, Büche leg. (1 specimen, MUSM); Río Putumayo, Soplín Vargas, 20.V.2010, Ramirez leg. (1 specimen [transitional to S. r. schatzi], MUSM); Río Sucusari, ExplornapoACEER, 12.IX.1995, Harvey leg. (1 specimen, MUSM); Río Utoquinía, Santa Sofía, 29-31.VII.1974, Lamas leg. (7 specimens, MUSM); Río Yarapa, Libertad, 14.IV.1988, Hornabrook leg. (1 specimen, MUSM); Yanamonos, 80 Km E Iquitos, 22.VII.1998, Lamas \& Mallet leg. (1 specimen, MUSM); Zona Reservada Sierra del Divisor, Río Yaquirana, $24.5 \mathrm{~km}$ SW de Constitución, 14-18.III.2009 (1 specimen, MUSM). San Martín: Navarro, 14.VIII.1974, Lamas leg. (1 specimen, MUSM). Ucayali: Pucallpa, 30.V.1974, Schunke leg. (1 specimen, MUSM); Pucallpa, 12.VII.1974, Schunke leg. (1 specimen, MUSM).

\section{ACKNOWLEDGEMENTS}

We thank Arnaldo Cabrera (Itaipú Binacional) and María Elena Ferreira (FACEN) for their assistance during the revision of the CE-MTG/IB specimens, as part of the Facultad de Ciencias Exactas y Naturales, Universidad Nacional de Asunción/Itaipú Binacional 2012 Curatorial project, as well as to the authorities of both institutions; Ezequiel Núñez-Bustos and Roberto R. Greve, for confirming the lack of records of Sais rosalia in Argentina and in the Parque Nacional do Iguaçu area (Paraná, Brazil), respectively; André Victor Lucci Freitas, Universidade Estadual de Campinas, for additional unpublished records and valuable comments; members of the Laboratório de Estudos de Lepidoptera Neotropical (LELN-UFPR) for additional help; and the Conselho Nacional de Desenvolvimento Científico e Tecnológico (CNPq, Brazil) for financial help to FMSD, MMC and OHHM.

\section{REFERENCES}

Brown, K.S. 1975. Geographical patterns of evolution in Neotropical Lepidoptera. Systematics and derivation of known and new Heliconiini (Nymphalidae: Nymphalinae). Journal of Entomology Series B, Taxonomy 44: 201-242.

Brown, K.S. 1979. Ecologia geográfica e evolução nas florestas neotropicais. São Paulo, Universidade Estadual de Campinas, xxxi+265 p.

Brown, K.S. 1987. Zoogeografia da região do Pantanal Mato-Grossense, p. 137-178. In: Anais do I Simpósio sobre Recursos Naturais e Sócio-Econômicos do Pantanal. Brasília, Embrapa, DDT.

Brown, K.S. \& Mielke, O.H.H. 1967. Lepidoptera of the Central Brazil Plateau. I. Preliminary list of Rhopalocera: Introduction, Nymphalidae, Libytheidae. Journal of the Lepidopterists' Society 21: 77-106.

Brown, K.S. \& Mielke, O.H.H. 1968. Lepidoptera of the Central Brazil Plateau. III. Partial list for the Belo Horizonte area, showing the character of the south-eastern "blend zone". Journal of the Lepidopterists' Society 22: $147-157$.

Bryk, F. 1953. Lepidoptera aus dem Amazonasgebiete und aus Peru gesammelt von Dr. Douglas Melin und Dr. Abraham Roman. Arkiv för Zoologi (N.S.) 5: 1-268.

Collenette, C.L. \& Talbot, G. 1928. Observations on the bionomics of the Lepidoptera of Matto Grosso, Brazil. Transactions of the Entomological Society of London 76: 391-416.

D’Almeida, R.F. 1978. Catálogo dos Ithomiidae americanos (Lepidoptera). Curitiba, Departamento de Zoologia, Setor de Ciências Biológicas, Universidade Federal do Paraná, iv+405 p.

D'Almeida, R.F. \& Fox, R.M. 1941. A revision of the genus Sais Hübner (Lepidoptera: Ithomiinae). Scientific Publications of the Reading Public Museum and Art Gallery 3: 1-5.

Drummond III, B.A. \& Brown Jr, K.S. 1987. Ithomiinae (Lepidoptera: Nymphalidae): summary of known larval food plants. Annals of the Missouri Botanical Garden 74: 341-358.

Fox, R.M. 1967. A monograph of the Ithomiidae (Lepidoptera). Part III. The tribe Mechanitini Fox. Memoirs of the American Entomological Society 22: $1-190$.

Freitas, A.V.L. \& Brown, K.S. 2002. Immature stages of Sais rosalia (Nymphalidae, Ithomiinae). Journal of the Lepidopterists' Society 56: 104-106.

Garwood, K., Lehman, R, Carter W. \& Carter, G. 2007. Butterflies of Southern Amazonia. A photographic checklist of common species. McAllen, RiCalé Publishing, viii+274 p.

Lamas, G. 1994a. Butterflies of the Explorer's Inn Reserve, p. 62-63. In: Foster, R.B., Carr, J.L. \& Forsyth, A.B. (Eds.). The Tambopata-Candamo Reserved Zone of Southeastern Perú:A Biological Assessment. RAP Working Papers 6, ii +184 p.

Lamas, G. 1994b. Butterflies of the Pampas del Heath, p. 73-74. In: Foster, R.B., Carr, J.L. \& Forsyth, A.B. (Eds.). The Tambopata-Candamo Reserved Zone of Southeastern Perú: A Biological Assessment. RAP Working Papers 6, ii+184 p.

Lamas, G. 1994c. List of Butterflies from Tambopata (Explorer's Inn Reserve), p. 162-177. In: Foster, R.B., Carr, J.L. \& Forsyth, A.B. (Eds.). The Tambopata-Candamo Reserved Zone of Southeastern Perú: A Biological Assessment. RAP Working Papers 6, ii+184 p.

Lamas, G. 1994d. List of Butterflies From Pampas del Heath, p. 178-184. In: Foster, R.B., Carr, J.L. \& Forsyth, A.B. (Eds.). The Tambopata-Candamo Reserved Zone of Southeastern Perú: A Biological Assessment. RAP Working Papers 6, ii $+184 \mathrm{p}$.

Lamas, G. 2004. Nymphalidae. Ithomiinae, p. 172-191. In: Lamas, G. (Ed.). Atlas of Neotropical Lepidoptera. Checklist: Part 4A. Hesperioidea - Papilionoidea. xxxvi +439 p.

Lanyon, W.E. 1982. The subspecies concept: Then, now and always. Auk 99: 603-604.

Mallet, J. 2007. Subspecies, semispecies, superspecies, p. 1-5. In: Levin, S.A. (Ed.). Encyclopedia of Biodiversity. Oxford, Elsevier.

Mielke, O.H.H. \& Casagrande, M.M. 1992. Lepidoptera: Papilionoidea e Hesperioidea coletados na Ilha de Maracá, com uma lista complementar de Hesperiidae de Roraima. Acta Amazonica 21: 175-210. 
Mielke, O.H.H. \& Casagrande, M.M. 1998. Papilionoidea e Hesperioidea (Lepidoptera) do Parque Estadual do Morro do Diabo, Teodoro Sampaio, São Paulo, Brasil. Revista Brasileira de Zoologia 14: 967-1001.

Motta, P.C. 2002. Butterflies from the Uberlândia region, central Brazil: Species list and biological comments. Brazilian Journal of Biology 62: 151-163.

Neild, A.F.R. 2008. The Butterflies of Venezuela. Part 2: Nymphalidae II (Acraeinae, Libytheinae, Nymphalinae, Ithomiinae, Morphinae). A comprehensive guide to the identification of adult Nymphalidae, Papilionidae, and Pieridae. Greenwich, London. Meridian Publications, $275 \mathrm{p}$.

Takahashi, M. 1977. A new species of the genus Sais (Lepidoptera: Danaidae Transactions of the Lepidopterological Society of Japan 28: $43-45$.
Warren, A.D., Davis, K.J., Stangeland, E.M., Pelham, J.P. \& Grishin, N.V. 2013. Illustrated lists of American butterflies (North and South America). Available at: http://butterfliesofamerica.com/L/Neotropical.htm (accessed 4 August 2013).

Wahlberg, N., Leneveu, J., Kodandaramaiah, U., Peña, C., Nylin, S., Freitas, A.V.L. \& Brower, A.V.Z. 2009. Nymphalid butterflies diversify following near demise at the Cretaceous/Tertiary boundary. Proceedings of the Royal Society B 276: 4295-4302.

Willmott, K.R. \& Freitas, A.V.L. 2006. Higher level phylogeny of the Ithomiinae (Lepidoptera: Nymphalidae): classification, patterns of larval hostplant colonization and diversification. Cladistics 22: 297-368.

Wilson, E.O. \& Brown, W.L. 1953. The subspecies concept and its taxonomic application. Systematic Zoology 2: 97-111. 